\title{
Prevalence and risk factors associated with Maedi-Visna infection in sheep in the State of Maranhão, Brazil
}

Prevalência e fatores de risco associados à infecção por Maedi-Visna em ovinos no Estado do Maranhão, Brasil

Prevalencia y factores de riesgo associados a la infección po Maedi-Visna em ovinos de Estado de Maranhão, Brasil

\author{
Michelle Lemos Vargens \\ ORCID: https://orcid.org/0000-0002-4691-3820 \\ Agência Estadual de Defesa Agropecuária do Maranhão, Brazil \\ E-mail: mixa-lemos27@hotmail.com \\ Margarida Paula Carreira de Sá Prazeres \\ ORCID: https://orcid.org/0000-0001-6791-3718 \\ Agência Estadual de Defesa Agropecuária do Maranhão, Brazil \\ E-mail: guidaprazeres@ hotmail.com \\ Rosiane de Jesus Barros \\ ORCID: https://orcid.org/0000-0002-3198-6576 \\ Agência Estadual de Defesa Agropecuária do Maranhão, Brazil \\ E-mail: rosianejbarros@gmail.com \\ Erlin Cely Cotrim Cavalcante \\ ORCID: https://orcid.org/0000-0002-5086-8364 \\ Laboratório de Bioprodutos, CERNITAS, Brazil \\ E-mail: erlincely@uol.com.br \\ Analy Castro Lustosa Cavalcante \\ ORCID: https://orcid.org/0000-0002-9217-3077 \\ Laboratório de Bioprodutos, CERNITAS, Brazil \\ E-mail: analylustosa@gmail.com \\ Mylena Andréa Oliveira Torres \\ ORCID: https://orcid.org/0000-0002-5021-3130 \\ Universidade Ceuma, Brazil \\ E-mail: mylena004822@ceuma.com.br \\ Tiago da Silva Teófilo \\ ORCID: https://orcid.org/0000-0002-3021-0880 \\ Universidade Federal Rural do Semi-Árido, Brazil \\ E-mail: tiago.teofilo@ufersa.edu.br \\ Daniel Praseres Chaves \\ ORCID: https://orcid.org/0000-0002-5320-1469 \\ Universidade Estadual do Maranhão, Brazil \\ E-mail:daniel@cernitas.com.br
}

\begin{abstract}
In order to determine Maedi-Visna virus (MVV) seroprevalence and risk factors associated with infection in sheep, 445 animals of both sexes and different ages were tested using the Agarose Gel Immunodiffusion technique (IDGA). The animals were divided into two groups: group 1 composed of exhibition animals $(n=70)$ and group 2 composed of animals from properties from the north, east and central mesoregions of the state of Maranhão $(n=375)$. The general prevalence of MVV infection was $2.02 \% ; 1.42 \%$ in group 1 and $2.13 \%$ in group 2 . In the north mesoregion the prevalence was $2.20 \%$, while a total of $40 \%$ of the animals living in municipalities for MVV. It was observed that $1.15 \%$ of males and $2.23 \%$ of females were seropositive ( $\mathrm{p}>0.20)$. Regarding breeds, the Dorper (1.66\%); Santa Inês (1.67\%); White Dorper $(33.33 \%)$ and Texel $(4.34 \%)$ were the most affected. This was the only variable among all the risk factors studied that had a significant association in multivariate analysis ( $p<0.05)$. MVV infection is present regardless of the purpose of breeding, and the animals are exposed to the same risk of infection. This demonstrates the need to implement public policies for the prevention, control, and eradication of this disease.
\end{abstract}

Keywords: Lentivirus; Ruminant; Epidemiology.

\section{Resumo}

Com o objetivo de determinar a soroprevalência do Maedi-Visna vírus (MVV) e os fatores de risco associados à infecção em ovinos, foram pesquisados através da técnica de Imunodifusão em Gel de Agarose (IDGA) 445 animais de ambos 
os sexos, de diferentes raças e idades, sendo 70 do grupo 1 (animais de exposição), e 375 do grupo 2 (animais de propriedades das mesorregiões Centro, Leste e Norte maranhenses). Constatou-se uma prevalência geral da infecção pelo MVV de 2,02\%, sendo 1,42\% no grupo 1 e 2,13\% no grupo 2. A mesorregião Norte apresentou prevalência de $2,20 \%$ sendo que, dos municípios da mesma, $40 \%$ dos animais estavam positivos para MVV. Observou-se que $1,15 \%$ dos machos e 2,23\% das fêmeas foram soropositivos ( $\mathrm{p}>0,20)$. Quanto às raças observou-se 1,66\% Dorper; 1,67\% Santa Inês; 33,33\% White Dorper e, 4,34\% para os da raça Texel, tendo sido a única variável entre todos os fatores de risco pesquisados, com associação significativa na análise multivariada ( $\mathrm{p}<0,05)$. A infecção por MVV está presente independente da finalidade de criação, estando estes, expostos ao mesmo risco de infecção pelo MVV. Alerta-se para a necessidade de implantação de políticas públicas de prevenção, controle e erradicação dessa enfermidade.

Palavras-chave: Lentivirus; Ruminante; Epidemiologia.

\section{Resumen}

Con el objetivo de determinar la seroprevalencia del virus Maedi-Visna (MVV) y los factores de riesgo asociados a la infección en ovinos, se investigó utilizando la técnica de Inmunodifusión en Gel de Agarosa (IDGA) 445 animales de ambos sexos, de diferentes razas y edades, siendo 70 del grupo 1 (animales expuestos) y 375 del grupo 2 (animales de propiedades de las mesorreriones Central, Este y Norte de Maranhão). Se constató una prevalencia general de la infección por MVV del 2,02\%, siendo 1,42\% en el grupo 1 y 2,13\% en el grupo 2. La mesorregión Norte tuvo una prevalencia del 2,20\%, siendo que, de los municipios de la misma, el 40\% de los animales fueron positivos para MVV. Se observó que el 1,15\% de los machos y el 2,23\% de las hembras fueron seropositivos (p>0,20). En cuanto a las razas, se observó un 1,66\% Dorper; 1,67\% Santa Inês; 33,33\% White Dorper y, 4,34\% para los de la raza Texel, habiendo sido la única variable entre todos los factores de riesgo encuestados, con asociación significativa en el análisis multivariado $(\mathrm{p}<0,05)$. La infección por MVV está presente independientemente de la finalidad creación, estando éstes, expuestos al mismo riesgo de infección por MVV. Se advierte de la necesidad de implementar políticas públicas para la prevención, control y erradicación de esta enfermedad.

Palabras clave: Lentivirus; Rumiante; Epidemiologia.

\section{Introduction}

Maedi-Visna (MV) is a chronic and progressive multisystemic disease that mainly affects sheep (Araújo et al., 2004; Lombardi et al., 2009). It is caused by an RNA virus belonging to the genus Lentivirus, family Retroviridae, subfamily Lentivirinae (Costa et al., 2007). The infection is characterized by the development of chronic inflammatory lesions in different organs, mainly in the lung, mammary gland and central nervous system (CNS). In the CNS, a histiocytic or lymphocytic inflammatory pattern is predominantly described (Gayo et al., 2018). Animals with a histiocytic pattern are easily recognizable by the ELISA test, whereas sheep with a lymphocytic lesion pattern may go unnoticed as seronegative and are probably a remnant source of infection (Gayo et al., 2017).

The disease is easily spread and handling conditions can favor the spread among animals. However, as the main routes of infection and transmission of the agent, direct contact with secretions rich in cells of the monocyte-phagocytic system, such as blood, milk or colostrum (Callado et al., 2001; Blacklaws et al., 2004; Silva \& Lima, 2007). In addition, transmission can occur mainly through respiratory exudates and secretions, most often facilitated between animals kept in confinement periods (Callado et al., 2001; Cortez-Romero et al., 2013).

Among the serological tests available, an Agarose Gel Immunodiffusion (AGID) is recommended by the World Organization for Animal Health (OIE) and is widely used for diagnosis of small Ruminants Lentivirosis the most used around the world (OIE, 2012).

Animal agglomerations represent an important link in the transmission of infectious diseases (Alves et al., 2017). In the absence of effective vaccines, a comprehensive understanding of the epidemiology of this diseare is of great importance to limit their spread. Many variables influence the expected costs and benefits of control programs and must be evaluated in order to implement measures that can lead to the control of this disease in sheep herds infections (Minguijón et al., 2015).

The economic damage caused by this disease is considerable, as it can result in severe weight loss in animals, reproductive failures, the need for early replacement of breeding stocks and matrices and death; as well as limiting international trade due to the sanitary barriers it can cause. The paucity of information about Maedi-Visna Virus (MVV), its distribution and 
dispersion has contributed to a lack of effective control measures. The aim of the present study was to determine the prevalence and identify risk factors associated with Maedi-Visna Virus in sheep from the State of Maranhão.

\section{Methodology}

The study was approved by the Ethics Committee in Animal Experimentation of the State University of Maranhão (CEAA/UEMA - 012/2013).

The animals selected for the present study were divided into two groups. Group 1 was composed of exhibition animals which participated in the $57^{\text {th }}$ Agricultural Exhibition of the state of Maranhão (EXPOEMA), and which belonged to exhibitors from the states of Pernambuco, Piaú and Maranhão. Group 2 was composed of animals raised in properties in the municipal regions of Itapecuru-Mirim, Paço do Lumiar, Raposa, Santa Rita, São José de Ribamar, São Luís (north mesoregion of state of Maranhão), São Luís Gonzaga (central mesoregion of state of Maranhão) and Timon (east mesoregion of state of Maranhão).

In total, 445 purebred sheep were included in the survey. Of these, 87 were male and 358 were female, aged from two months to eight years, of the Dorper, Santa Inês, White Dorper and Texel breeds.

The number of animals in Group 1 was determined by the non-probabilistic sampling technique (Thrusfield, 2004). The owners were selected by voluntary participation after signing a free and informed consent form. A total of 70 animals ( 35 female and 35 male) of the Dorper, Santa Inês and White Dorper breeds were selected.

Data provided by the Brazilian Association of Sheep Breeders (ARCO) from the year 2012 was used to determine the amount of animals in Group 2. The number of samples was determined by simple randomization, according to Triola (1999) and Callegari-Jacques (2003), based on an expected prevalence of 50\%, a sample error of 5\% and a confidence level of 95\%, resulting in a minimum of 361 animals. Property selection was carried out by voluntary participation, irrespective of the number of animals in each property. Samples of all the defined-breed sheep present on the selected properties were collected, totaling 375 animals (52 males and 323 females) of the Dorper, Santa Inês, White Dorper and Texel breeds.

A total of $10 \mathrm{~mL}$ of blood was collected from the external jugular vein. The samples were conditioned and sent to the Veterinary Clinical Pathology Laboratory of the State University of Maranhão (UEMA). The serum was placed in microtubes and stored at $-20^{\circ} \mathrm{C}$ until the serological tests were performed.

The detection of Maedi-Visna virus antibodies was performed using the agar gel immunodiffusion technique (AGID), with a commercial kit (Biovetech ${ }^{\circledR}$, Recife, Pernambuco, Brazil) and following the manufacturer's recommendations. Two readings were performed, one after $24 \mathrm{~h}$ and one after $48 \mathrm{~h}$, by three independent observers. The result was considered that taken after the second reading. Samples that tested positive were repeated three times to confirm the result.

Properties were considered positive for the presence of the Maedi-Visna Virus when at least one reagent animal was found. First, the prevalence of seropositive animals was estimated and then a descriptive statistical analysis of the groups by sex, breed and age was performed. The frequencies in the studied strata were calculated based on the serological results by simple percentage.

The variables that were related in the epidemiological survey allowed the study of risk factors. A database was generated, with the animal considered to be an epidemiological unit, to identify which of the studied factors were associated with the Maedi-Visna virus. The logistic regression model was used (Hosmer \& Lemeshow, 1989).

Data were analyzed in the STATA 9.0 program. Univariate analysis of each independent variable was performed by selecting those with a p-value $<0.20$. Subsequently, the combined association of the factors studied with respect to the occurrence of Maedi-Visna was analyzed using the multivariate logistic regression technique, with only the variables that presented a pvalue $<0.05$ remaining in the model. Prevalence ratios (PR) and 95\% confidence intervals were estimated. The level of 
significance adopted was 5\%. The comparison of the frequencies between groups was performed by the chi-squared test and logistic regression analysis was used to identify risk factors with a significant association with seropositivity.

\section{Results}

Of the total number of animals evaluated, $19.55 \%$ (87/445) were male and $80.45 \%$ (358/445) were female. Seroprevalence was $1.15 \%$ (1/87) in males and $2.23 \%(8 / 358)$ in females. Among the positive animals, there was a predominance of females, with $88.9 \%$ (8/9), while only $11.10 \%$ (1/9) of positive cases were male. No risk association was found between sex and the occurrence of the disease ( $p>0.20)$ (Table 1).

Table 1. Risk factors associated with the occurrence of the Maedi-Visna Virus (MVV) in non-defined breed sheep in the State of Maranhão (2014).

\begin{tabular}{|c|c|c|c|c|}
\hline Variable & Reagents/exposed & $\%$ & Odds ratio & $P$ value \\
\hline \multicolumn{5}{|l|}{ Sex } \\
\hline Female & $8 / 358$ & 2.23 & & \\
\hline Male & $1 / 87$ & 1.15 & 0.51 & 0.53 \\
\hline \multicolumn{5}{|l|}{ Age } \\
\hline$<12$ months & $1 / 76$ & 1.31 & & \\
\hline $12-16$ months & $1 / 32$ & 3.12 & 2.42 & 0.53 \\
\hline 17-22 months & $0 / 15$ & 0 & & \\
\hline 23-36 months & $1 / 119$ & 0.84 & 0.63 & 0.75 \\
\hline 37-48 months & $1 / 51$ & 1.96 & 1.5 & 0.78 \\
\hline$>48$ months & $5 / 152$ & 3.28 & 2.55 & 0.39 \\
\hline
\end{tabular}

$* * p<0.20$ - statistically significant. Source: Authors.

In terms of age, $17.07 \%$ (76) of the animals were up to 12 months old; 7.20\% (32) were aged between 12 and 16 months; $3.37 \%$ (15) between 17 and 22 months; 26.75\% (119) between 23-36 months; $11.46 \%$ (51) between 37 and 48 months and the largest portion of the sample, 34.15\% (152), was aged over 48 months. This older age group also contained the largest number of reactive animals, with 3.28\% (5/9). Univariate logistic regression analysis did not reveal a statistically significant association ( $>0.20$ ) between age group and the occurrence of MVV (Table 1).

The general prevalence of the Maedi-Visna Virus (MVV) without clinical signs characteristic of the disease was 2.02\% $(9 / 445,95 \% \mathrm{CI}=[0.93-3.80])$. The breed $(\mathrm{OR}=29.5$, CI 95\% $=[1.83-474.41])$, amount of animals in the property $(\mathrm{OR}=10.1$, $\mathrm{CI} 95 \%=[1.05-96.61])$, type of updating of knowledge of breeders $(\mathrm{OR}=8.6,95 \% \mathrm{CI}=[0.46-159.83])$ and feeding of lambs $(\mathrm{OR}=10.63,95 \% \mathrm{CI}=[1.09-103.23])$ had a statistically significant relationship $(\mathrm{p}<0.20)$ with the MVV infection of the animals in the univariate logistic regression analysis of risk factors (Table 2). 
Table 2. Risk factors for Maedi-Visna Virus in defined breed sheep in the State of Maranhão (2014).

\begin{tabular}{lllll}
\hline Breed & Reagents/exposed & \% & Odds ratio & P value \\
\hline Dorper & $2 / 120$ & 1.66 & & \\
Santa Inês & $5 / 299$ & 1.67 & 1.00 & 0.99 \\
White Dorper & $1 / 3$ & 33.33 & 29.5 & $0.02 * *$ \\
Texel & $1 / 23$ & 4.34 & 2.68 & 0.43 \\
& & & & \\
\hline
\end{tabular}

$* * \mathrm{p}<0.05$ - statistically significant. Source: Authors.

Variables with a p value less than $0.20(\mathrm{p}<0.20)$ were included in the multivariate logistic regression model; the "breed" variable was the only risk factor with a statistically significant association ( $\mathrm{p}<0.05$ ). White Dorper animals were 44 times more likely to be infected with MVV than the other breeds tested. Reagent animals were observed in all the evaluated breeds; $1.66 \%$ (2/120) for the Dorper breed, 1.67\% (5/299) for Santa Inês, 33.33\% (1/3) for White Dorper and 4.34\% (1/23) for Texel (Table 2).

Of all the positive animals, $2.20 \%$ (9/409) were from the north mesoregion of the state of Maranhão. Of all the municipal regions, $40 \%(4 / 10)$ had at least one property with a seropositive animal.

A prevalence of $1.42 \%$ (1/70) in group 1 and 2.13\% (8/375) in group 2 was observed (Table 3$)$. In terms of the overall prevalence of the disease, Group 1 had $0.22 \%$ of seropositive animals and group 2 had $1.80 \%$ of seropositive animals. Statistical analysis, however, revealed that the frequencies of MVV did not differ between the groups.

Table 3. Prevalence of Maedi-Visna, per group of sheep tested by agarose gel Immunodiffusion (AGID) in the State of Maranhão (2014).

\begin{tabular}{|c|c|c|c|c|}
\hline Group & Reagents/tested animals & $\begin{array}{c}\text { Reagents } \\
(\%)^{1}\end{array}$ & $\begin{array}{c}\text { Reagents } \\
(\%)^{2}\end{array}$ & $\chi^{2}(*)$ \\
\hline $1^{*}$ & $1 / 70$ & 1.42 & 0.22 & \multirow{2}{*}{0.15} \\
\hline $2^{*}$ & $8 / 375$ & 2.13 & 1.80 & \\
\hline
\end{tabular}

${ }^{1}$ Percentage of reactive sheep compared to the total tested in each stratum.

${ }^{2}$ Percentage of reagents sheep compared to all animals tested in the study.

$* \chi^{2}$ values $>$ than 3.84 - significant association with $p$ value.

Source: Authors.

\section{Discussion}

The general prevalence of the Maedi-Visna (MV) found in this study is considered low by Reina et al. (2009) (1 to 9\%), and is similar to that observed in other states where a semi-extensive breeding system also predominates. This may be related to the recent introduction of the virus in the region and to the fact that this rate varies greatly in purebred animals, according to Batista et al. (2004).

Low prevalences were also found in the state of Pernambuco (1.1\%) by Costa et al. (2007), Bahia $(0.5 \%$ and $0.34 \%)$ by Souza et al. (2007) and Martinez et al. (2011) and in Tocantins (0.9\%), by Moura Sobrinho et al. (2008). In studies conducted by Guilherme et al. (2017), none of the animals tested were positive for MVV. Gregory et al. (2013) evaluated 226 sheep samples from the state of São Paulo, in the microregions of Botucatu, Campinas, Piedade and São Paulo, and found that none of the samples were seroreagent. 
The analysis of risk factors for the occurrence of MV revealed a result that contradicted the findings of Moura Sobrinho et al. (2008) and Lombardi et al. (2009). However, results presented in this work corroborate with data from Sobrinho et al. (2010) findings of the present study, as they also found a significant association between breed and the occurrence of Lentivirosis in small ruminants in the state of Tocantins. Callado et al. (2001) stated that breed susceptibility could not be identified, as the studies are difficult to interpret due to various factors related to handling.

The null prevalence found in the other states surveyed and in the central and east mesoregions can be explained by the reduced number of animals tested. However, the presence of reactive sheep in the north mesoregion may be due to the fact that this region had the highest concentration of sheep breeders in the study area, as well as the greatest number of cities, properties and animals sampled. Teixeira et al. (2016) observed an overall prevalence of MVV of $0.7 \%$, and prevalences of $0.5 \%, 0.7 \%$ and $1 \%$ in the central, eastern and northern mesoregions of the state of Maranhão, respectively.

Studies carried out by Moura Sobrinho et al. (2008) observed that there was a numerically greater number of positive cases among animals of the Santa Inês breed (6/511) than among non-defined breed animals (2/324). However, no significant association was found between breed and MVV occurrence. In the results obtained by Teixeira et al. (2016) there was no association between seropositivity and the breed affected.

The lack of risk association between sex and the occurrence of the disease ( $p>0.20)$ corroborates the results of Lombardi et al. (2009) and Sobrinho et al. (2010). The same was observed between age group and the occurrence of MVV, similar to the findings of Moura Sobrinho et al. (2008). In the study by Alves et al. (2017), all the sheep male were negative and 6.72\% (8/119) sheep female were seropositive. Teixeira et al. (2016) observed that $0.5 \%$ (1/207) of seropositive sheep were male and $0.8 \%$ $(10 / 1288)$ were female.

The claim that MVV infection can affect animals of any age was verified in studies by Rowe \& East (1997), where it was observed that animals aged less than one year and older than 48 months were seropositive, and that a higher percentage of infection was found in the latter stratum (5/9 - 3.28\%). According to Snowder et al. (1990) and Cutlip et al. (1992), older animals are exposed to the infectious agent for a longer period while seroprevalence tends to be higher in this age group, as it is a chronic disease with a long, slow course, allowing the confirmation of seroconversion. Teixeira et al. (2016) also found that there was no significant difference in this variable.

There were no animals with clinical signs of MVV, probably due to the long incubation period of the virus, a finding similar to the observations of Araújo et al. (2004), Souza et al. (2007) and Lombardi et al. (2009). This result reinforces the hypothesis that the infections are recent.

\section{Conclusion}

Maedi-Visna Virus infection is present in non-defined breed sheep in the state of Maranhão, and all sheep are exposed to the same risk of infection irrespective of the purpose of breeding. The occurrence of Maedi-Visna indicates the need to implement preventive and control measures, especially as these animals are used as herd enhancers, and have the capacity to spread the disease quickly and across a large geographic area.

\section{Acknowledgments}

The authors would like to thank the Agência de Defesa Agropecuária do Estado do Maranhão (AGED/MA), the Fundo de Desenvolvimento Pecuário do Maranhão (FUNDEPEC), the Universidade Estadual do Maranhão (UEMA) and the PostGraduation Program on Animal Defense. 


\section{Ethics Committee in Animal Experimentation}

The study was approved by the Ethics Committee in Animal Experimentation of the State University of Maranhão (CEAA/UEMA - 012/2013).

\section{References}

Alves, J. R. A., Limeira, C. H., Lima, G. M. de S, Pinheiro, R. R., Alves, F. S. F., Santos, V. W. S. dos, Azevedo, S. S. \& Alves, C. J. (2017). Epidemiological characterization and risk factors associated with lentiviral infection of small ruminants at animal fairs in the semiarid Sertão region of Pernambuco, Brazilian semiarid. Semina Ciências Agrárias, 38, 1875-1886.

Araújo, S. A. C., Dantas, T. V. M., Silva, J. B. A., Ribeiro, A. L., Ricarte, A. R. F. \& Teixeira, M. F. S. (2004). Identificação de Maedi-Visna vírus em pulmão de ovinos infectados naturalmente. Arquivos de biologia e tecnologia, 71, 431-436.

Batista, M. C. S., Castro, R. S., Carvalho, F. A. A., Cruz, M. S. P., Silva, S. M. M. S., Rego, E. W. \& Lopes, J. B. (2004). Anticorpos anti lentivírus de pequenos ruminantes em caprinos integrantes de nove municípios piauienses. Ciência Veterinária dos Trópicos, 7, 75-81.

Blacklaws, B. A., Berriatua, E., Torsteinsdottir, S., Watt, N. J., Andres, D. de, Klein, D. \& Harkiss, G. D. (2004). Transmission of small ruminant lentiviruses. Veterinary Microbiology, 101, 199-208.

Callado, A. K. C., Castro, R. S. de \& Teixeira, M. F. da S. (2001). Lentivírus de pequenos ruminantes (CAEV e Maedi-visna): revisão e perspectivas. Pesquisa Veterinária Brasileira, 21, 87-97.

Callegari-Jacques, S. M. (2003). Testes não paramétricos. In: Bioestatística: Princípios e aplicações. Artmed, 256.

Cortez-Romero, C., Pellerin, J. L., Ali-Al-Ahmad, M. Z., Chebloune, Y., Gallegos-Sánchez, J., Lamara, A., Pépin, M. \& Fieni, F. (2013). The risk of small ruminant lentivirus (SRLV) transmission with reproductive biotechnologies: state-of-the-art review. Theriogenology, 79, 1-9.

Costa, P. S. P., Lima, P. P. de, Callado, A. K. C., Nascimento, S. A. do \& Castro, R. S. de (2007). Lentivírus de pequenos ruminantes em ovinos Santa Inês: isolamento, identificação pela PCR e inquérito sorológico no Estado de Pernambuco. Arquivos do Instituto de Biologia, 74, $11-16,2007$.

Cutlip, R. C., Lehmkuhl, H. D., Sacks, J. M. \& Weaver, A. L. (1992). Seroprevalence of ovine progressive pneumonia virus in sheep in the United States as assessed by analyses of voluntary submitted samples. American Journal of Veterinary Research, 53, 976-979.

Gayo, E., Polledoa, L., Preziusob, S., Rossib, G., Balseiroc, A., Pérez Martíneza, C., García Iglesiasa, M. J. \& García Marína, J. F. (2017). Serological Elisa results are conditioned by individual immune response in ovine maedi visna. Small Ruminant Research, 157, 27-31.

Gayo, E., Polledo, L., Balseiro, A., Pérez Martínez, C., García Iglesias, M. J., Preziuso, S., Rossi, G. \& García Marín, J. F. (2018). Inflammatory Lesion Patterns in Target Organs of Visna/Maedi in Sheep and their Significance in the Pathogenesis and Diagnosis of the Infection. Journal of Comparative Pathology, 159, 49-56.

Guilherme, R. F., Azevedo, S. S., Higino, S. S. S., Alves, F. S. F., Santiago, L. B., Lima, A. M. C., Pinheiro, R. R. \& Alves, C. J. (2017). Caracterização epidemiológica e fatores de risco associados à infecção por lentivírus de pequenos ruminantes na região do semiárido paraibano, Nordeste do Brasil. Pesquisa Veterinária Brasileira, 37, 544-548.

Hosmer, D. W. \& Lemeshow, S. (2000). Applied Logistic Regression, 2, Wiley-interscience Publication, 397.

Lombardi, A. L., Nogueira, A. H. C., Feres, F. C., Paulo, H. P., Castro, R. S., Feitosa, F. L. F., Cadioli, F. A., Peiró, J. R., Perri, S. H. V., Lima, V. F. M. \& Mendes, L. C. N. (2009). Soroprevalência de Maedi-visna em ovinos na região de Araçatuba, SP. Arquivos Brasileiro de Medicina Veterinária, 61, $1434-1437$.

Martinez, P. M., Costa, J. N., Souza, T. S., Lima, C. C. V. de, Costa-Neto, A. de O. \& Pinheiro, R. R. (2011). Prevalência sorológica da maedi visna em rebanhos ovinos da Microrregião de Juazeiro - Bahia por meio do teste de imunodifusão em gel de ágar. Ciência Animal Brasileira, 12, 322-329.

Minguijón, E., Reina, R., Pérez, M., Polledo, L., Villoria, M., Ramírez, H., Leginagoikoa, I., Badiola, J. J., García-Marín, J. F., Andrés, D. de, Luján, L., Amorena, B., \& Juste, R. A. (2015). Small ruminant lentivirus infections and diseases. Veterinary Microbiology, $181,75-89$.

Moura Sobrinho, P. A. M., Fernandes, C. H. C., Ramos, T. R. R., Campos, A. C., Costa, L. M. \& Castro, R. S. (2008). Prevalência e fatores associados à infecção por lentivirus de pequenos ruminates em ovinos no Estado do Tocantins. Ciência Veterinária nos Trópicos, 11, 65-72.

OIE, World Organisation for Animal Health (2012). Manual of Diagnostic Tests and Vaccines for Terrestrial Animals of the World Organisation for Animal Health, 2(4): 441-442.

Reina, R., Berriatua, E., Luján, L., Juste, R., Sánchez, A., Andrés, D. de \& Amorena, B. (2009). Prevention strategies against small ruminant lentiviruses: An update. The Veterinary Journal, 182, 31-37.

Rowe, J. D. \& East, N. E. (1997). Risk factors for transmission and methods for control of caprine arthritis-encephalitis virus infection. Veterinary Clinics of North America: Food Animal Practice, 13, 34-53.

Silva, J. B. A. \& Lima P. M. (2007). Lentivírus de pequenos ruminantes: caracterização etiológica, infectividade, controle, prevenção e diagnóstico. Acta Veterinária Brasileira, 1, 111-117.

Snowder, G. D., Gates, N. L., Glimp, H. Á. \& Gorham, J. R. (1990). Prevalence and effect of subclinical ovine progressive pneumonia virus infection on ewe wool and lamb production. Journal of the American Veterinary Medical Association, 197, 475-479. 
Research, Society and Development, v. 10, n. 5, e2210514440, 2021

(CC BY 4.0) | ISSN 2525-3409 | DOI: http://dx.doi.org/10.33448/rsd-v10i5.14440

Sobrinho, P. A., Ramos, T. R. R., Fernandes, C. H. C., Campos, A. C., Costa, L. M. \& Castro, R. S. (2010). Prevalência e fatores associados à infecção por lentivírus de pequenos ruminantes em caprinos no estado do Tocantins. Ciência Animal Brasileira, 11, 117-124.

Souza, T. S., Costa, J. N., Martinez, P. M. \& Pinheiro, R. R. (2007). Estudo sorológico da Maedi-visna pelo método da imunodifusão em gel de ágar em rebanhos ovinos de Juazeiro, Bahia, Brasil. Revista Brasileira de Saúde e Produção Animal, 8, 276-282.

Teixeira, W. C., Azevedo, E. O., Nascimento, S. A., Mavulo, M. F. V., Rizzo, H., Silva, J. C. R. da \& Castro, R. S. de (2016). Soroprevalência de Maedi-visna em rebanhos ovinos do estado do Maranhão, Brasil. Revista Brasileira de Medicina Veterinária, 23, 1-2.

Thrusfield, M. (2004). Epidemiologia Veterinária, Roca, 556.

Triola, M. F. (1999). Introdução à Estatística, 7, LTC. 